\title{
The impact of relief on the distribution of the population in the area of East Sarajevo
}

\author{
Mariana Lukić Tanović \\ Jelena Golijanin \\ Milka Grmusa \\ University of East Sarajevo, Faculty of Philosophy, Department of Geography \\ mariana.lukic@gmail.com
}

DOI:10.5901/mjss.2014.v5n22p176

\begin{abstract}
Bosnia and Herzegovina, and therefore the City of East Sarajevo have in recent decades been affected by large demographic changes, primarily caused by the war that caused the population emigration population and, together with the process of demographic transition, characterized by a negative natural growth, have led to the depopulation, an aging of population, reduced life quality and low standard of living. The City of East Sarajevo is located in the eastern part of Bosnia and Herzegovina and it consists of six municipalities: East New Sarajevo, Pale, East Ilidža, East Old Town, Sokolac and Trnovo, with about 216 settlements. It covers an area of approximately 1, $425 \mathrm{~km}^{2}$ and in hypsometric sense, these settlements are located between 500 and $1916 \mathrm{~m}$ of altitude. The morphometric features of the terrain, the horizontal and vertical articulation of relief, slope and elevation of the terrain, exposure, etc. have a major impact on the distribution of the settlement. The subject of this paper will be geographical and habitation specifics of East Sarajevo, vertical zones and distribution of the population. The aim of this paper is to determine whether and how the relief affects the distribution of the population in the researched area and how population depends on the morphometric parameters. Also, we want to determine how the population of mountainous landscapes of the explored territory has changed and what is its trend of the last few decades, since the process of migration from rural to urban areas and the process of land reclamation is expressed throughout the territory of Bosnia and Herzegovina. As a hypothesis, there is the depopulation that is more prominent in areas with higher altitude, and, through the paper we will examine and try to relate the movement of the population and hypsometric distribution of the population. The higher mountainous areas are more affected by intensive aging population, demographic fragmentation and the creation of rural built.
\end{abstract}

Keywords: Population, morphometric characteristics of the relief, the settlement, the City of East Sarajevo

\section{Introduction}

The City of East Sarajevo is situated in the central and eastern part of Bosnia and Herzegovina, that is, the eastern part of Republic of Srpska. The city is comprised of six municipalities: East New Sarajevo, East llidža, Pale, Sokolac, Trnovo and East Old Town. The territory of East Sarajevo includes two parts: a greater northern part (1380.61 km2) and a far smaller southern part (45.16 km2).

Republic of Srpska was internationally established after the Civil War (1992-1995) by Dayton Peace Agreement (November 1995) which divided the country Bosnia and Herzegovina into two entities: Republic of Srpska, $49 \%$ of BH territory, and The Federation of Bosnia and Herzegovina, 51\% of BH territory (Lukić Tanović, Pašalić \& Golijanin, 2014).

The present area of the City of East Sarajevo once belonged to the City of Sarajevo, the BH capital, until 1992. The City of Srpsko Sarajevo, later known as East Sarajevo, was formed from the Sarajevo municipalities with predominantly Serbian population.

The previous war was the cause of population regrouping based on their nationality, territory and location. Socially and geographically speaking, the entity border deconstructed the settlement system which was the result of long time period and specific historical, social and economic conditions. The urban network of $\mathrm{BH}$ had negligible role in the entity demarcation. Considering complexity of political, territorial and administrative division of $\mathrm{BH}$, it is understandable that it caused the breach in the settlement network. The entity border has divided 304 settlements. The process of settlement disintegration is mostly expressed in the north-eastern parts of $\mathrm{BH}$ and in the area of Sarajevo. A special example presents 
the Old City municipality where the entity border divided 6 of the total 16 pre-war settlements. The level of disintegration within this municipality (total and divided settlement relation) is $37.5 \%$ (Musa, 2005).

\section{Methodology}

After gathering necessary literature and material, the first phase in writing this paper is the analysis of available material. The analysis includes basic land relief, demographic and settlement characteristics of the City of East Sarajevo. The next step after analytical research is synthesis that will determine to what extent relief characteristics influence the dislocation of the population, that is, to what extent the population depends on morphometric parameters. The methods used for processing the gathered material are mathematical-statistical method, classification, cartographic method, systematization, comparative method, generalization, description, etc.

For the analysis of morphometric indicators and subsequent comparison of relief influence and population dislocation in the territory of East Sarajevo, DEM data SRTM from the year 2000 were used. Based on DEM resolution 90x90, which is satisfactory resolution for the research undertaken in this paper, the following results were achieved: morphometric relief charts, analysis of area data and statistical parameters, used for comparison of relief influence and population dislocation. For all these actions, GIS tools were used (program package ArcGIS 10.1).

All settled areas of the mentioned territory were located and charted with the use of GIS and topographic charts since the data sources on population dislocation on the territory of the City of East Sarajevo were mainly the official statistical institutions of $\mathrm{BH}$, which grouped the number of inhabitants according to the settled municipalities. In order to achieve more precise spatial analysis, subsequent data comparison and greater objectivity (and due to the lack of data about settlement borders), the procedure of determining "working" settlement acreage was conducted. For the above, the graphic method was used by which the circle of $1000 \mathrm{~m}$ radius was made around earlier charted points of every settlement. This is how land area dimensions of the particular settlements were derived. Also, it is necessary to mention that acreage of specific settlements passes over the borders of the neighbouring municipalities and even the entity border. This is specifically the case with municipalities of Trnovo and East Old Town. The research results of the relief influence on the population dislocation in the territory of East Sarajevo are represented graphically in charts, diagrams and tables.

\section{Relief particularities of the City of East Sarajevo}

The area of East Sarajevo is located $500 \mathrm{~m}$ above the sea level and has mountain characteristics. Almost $70 \%$ of the town territory has altitude between 800 and $1200 \mathrm{~m}$. The altitude below $600 \mathrm{~m}$ takes only $1,92 \%$ of the territory and the altitude above $1500 \mathrm{~m}$ takes $2,23 \%$ of the territory. Among the town municipalities, East Old Town has the biggest average altitude. The lowest point is $510 \mathrm{~m}$ and it is situated in the valley of Željeznica River on the border of the settlement Vojkovići. The highest point is on the mountain Jahorina, called the Ogorjelica peak with the altitude of $1916 \mathrm{~m}$.

In morphology of the researched area, the following river valleys are differentiated: Prača, Željeznica, Tilava, Paljanska Mlljaca, Mokranjska Miljacka, Bioštica, and Kaljina. Most prominent ravines are Sarajevska and Paljanska ravines and of the vast plateaus, Glasinac plateau is to be distinguished. Among these, massifs over $1000 \mathrm{~m}$ situated here are: Jahorina, Trebević, Romanija, Ozren, Devetak.

In relief morphology, the distinguished traits are the ravines of Kaljina and Bioštica in the municipality of Sokolac, Miljacka Ravine in the East Old Town municipality, and Paljanska Miljacka Ravine in the municipality of Pale. In the southernmost areas of the city, Trnovo municipality, the most domineering point is Treskavica Massif with the peak Lupoc $(1776 \mathrm{~m})$. North to Trnovo, there is the morphological unit Trebević- Ravna Planina- Jahorina. On the northern parts of Jahorina, the located faults separate karstified areas of Ravna Planina and Trebević from Jahorina. Romanija Mountain dominates the area northeast to Pale and west to Sokolac with the peaks Velika stijena (1617 m), Djeva (1573 m) and others (Institute of Planning Republc of Srpska, 2008). The west part of Romanija is greatly kartisified plateau with many sinkholes and other karstified forms. The west part of this mountain is predisposed to faults, so that crumbled rocks is accumulated below vertical cliffs. Flat areas, which were formed by deposition of the quaternary deposits on limestone or Miocene sediments, are: Glasinačko and Luburic polje, Kovanj, Batovo, Pale and so on. Among the genetic relief forms there are those of fluvialdenudation, fluvial- karst, karst and fluvial-accumulative land forms (Golijanin, 2012).

\section{Demographic and settlement particularities of the City of East Sarajevo}


After 22 years, in October 2013, the census took place in Bosnia and Herzegovina, so that for now the preliminary census data are available for demographic research purposes.Data regarding 1971, 1981 and 1991 for the present territory of East Sarajevo, were received from the official institutions involved in population statistics (Croatian Bureau of statistics Republic of Croatia, 1995). Based on these, the data summarization and the redistribution among municipalities that are presently past of East Sarajevo were conducted.

According to 1991 census, the present territory of East Sarajevo was populated by 44, 430 inhabitants1. According to the same census, the City of Sarajevo had population of 527, 049 inhabitants, so that only 8, $43 \%$ of the inhabitants of Sarajevo belonged to the present territory of East Sarajevo, excluding Sokolac municipality.

Many crucial social and economic changes occurred during the war (1992-1995), affecting the demographic changes and their precise assessment. Especially the war migrations caused such demographic situation in the territory of East Sarajevo. In 1996, 48, 3 \% of the city population was categorized as refugees or displaced persons, and in 2001 the number was 32 , $9 \%$. War migrations influenced gross reproduction rate and decline in natural increase rate, as well as disruption in gender, age, ethnic, education and economic structure of the city population.

However, migration balance of internal migration in East Sarajevo in the last five years has been positive: the population inflow is greater than population outflow. In 2013, according to the preliminary census results (Institute of Statistics Republic of Srpska, 2013), the City of East Sarajevo has the population of 64,966 , that is 20,536 persons more than in the initial period of the town building, meaning that in the last 20 years the number of persons in the territory of East Sarajevo increased for $46,3 \%$.

Since 1996, one of the biggest demographic problems of the city is the negative natural increase. The problem of low birth rate has not been adequately tackled neither by local nor the state authorities, in the sense that no adequate measures were undertaken as way of solving this problem (Lukić, 2011).

Dislocation of both the population and the settlements in the territory of the city was influenced by morphological land characteristics, climate, microclimate, hydrological characteristics and so on. The settlements are located in hypsometric zone ranging from $510 \mathrm{~m}$ to $1,500 \mathrm{~m}$. The highest settlements are on the hillsides of Treskavica and Jahorina mountains, and the lowest are located in Sarajevo valley.

From the total of 216 inhabited places, only 5 are urban/city settlements and also municipality centres in which the highest number of population is situated. The city settlements note increase in the number of inhabitants, mostly because of the mechanical afflux of population and country-city migrations.

In rural areas there is demographic depletion and settlement decrement, so that consequently the following processes appear: depopulation, deruralization, disaggregation, country-city migrations, emergence of aging households, but also demographic withering of vast number of country settlements (Ivković \& Todorić, 2013).

By analyzing the number of population in the populated places, we can conclude that the settlements ranging from 10-49 inhabitants dominate in the territory of the City of East Sarajevo, or expressed in percentage- $32,5 \%$. The disturbing fact is that $25 \%$ of populated places has less than 10 inhabitants, while this percentage in 1991 was $6 \%$, in $19814,2 \%$ and in 1971 only $1,4 \%$. Apart from extremely small number of inhabitants, these settlements have also very unfavourable age structure and very difficult conditions for possible demographic revitalization. Unless in the subsequent period migration of younger population and investment in the development of country economy happens, the preconditions are that these settlements will completely wither. Contrary to this and as the confirmation of the hypothesis that demographic growth is apparent in the city areas, two settlements over 10, 000 inhabitants could be distinguished in 2013. In 5 city settlements there are 42,600 inhabitants, that is $65,6 \%$ of the total population, while in the remaining 211 rural areas there are 22 , 366 inhabitants, that is $34,4 \%$.

\section{The analysis of the relief influence on population dislocation}

The fact that the relief forms the landscape and that all social activities are here performed contributes to it as an important role in distribution of economic activities and population as well. In the researched areas four hypsometric zones are evident:

Southeast part of Sarajevo Polje, altitude $510 \mathrm{~m}$ and more,

1 Considering the mentioned problem of bordering between settlements, the number of population in East Sarajevo territory for 1991,1981 and 1971 is imprecise, aproximatelly determined population number. 
Hill relief with plains and plateaus, $800-1000 \mathrm{~m}$

Middle mountain relief, $1000-1500 \mathrm{~m}$

High mountain relief with peaks: Jahorina (1916m), Treskavica (1776m), Romanija (1652m), Trebević (1629m), Ozren (1453m), Devetka (1424m).

Based on the census data and the analysis of the influence of the relief and population number according to the last census results, it is noted that population dislocation and population itself correspond to stated hypsometric classes. Areas belonging to Sarajevsko Polje, mostly parts of the municipalities of East llidža and East New Sarajevo, as lower altitudes distinguish as more favourable for settlement and urbanization. The population number on the lowest hypsometric zone in the researched area is 27,338 inhabitants or $42 \%$. However, in the second hypsometric zone, the population conditions are also favourable since the population number is the greatest $(50,9 \%$ or 33,155 inhabitants), that is more than half of the population in the researched area live precisely in this zone.

The settlements in Pale and Trnovo basins, as well as the settlement on Sokolac plateau, enter this hypsometric zone with heights 800-900 m which are dominantly the most populated in the territory of East Sarajevo. In the zone dominated by middle mountain relief, the population number disturbingly decreases and these areas have lower population density (4, 544 or $7 \%$ of the inhabitants live in places located between 1000-1500 m), while the highest areas of the city territory are almost unpopulated. In the highest hypsometric zone, there are two settlements (Jahorina and Kozja Luka) with potentials for development of tourism and forestry. The relation between hypsometric relief characteristics and population distribution, according to different census periods, are shown in Table 1. and Chart 1.

Data in Chart 1. clearly show the differences between hypsometric relief characteristics and population distribution, according to different census periods. Generally, population growth is evident over the time, especially in the first two hypsometric zones. Also, the decrease or stagnation in population number is evident in the higher areas of the researched territory.

By analyzing and comparing the influence of sloping relief on population distribution on analyzed area, it is concluded that the highest number of inhabitants $(42278,65 \%)$ is situated on mildly sloping terrain with slopes ranging between $2-5^{\circ}$. However, more than half of settlements are located on the sloping terrain with slopes ranging from $5-12^{\circ}$. Mainly this is the case with rural settlements with the population decrease trend which is clearly presented in Table 2. and Chart 2. 12, 349 inhabitants were located in the sloping terrain, which is $19 \%$ of the total population number in the territory of the city. In the slightly sloping terrain with categories of slopes ranging from $12-32^{\circ}$, there are 6,931 inhabitants $(10,6 \%)$. The number of settlements registered in these slope categories is also considerately high, but the number of inhabitants in these areas decreased by almost half in the last 40 years. This is mostly the case with rural areas situated in higher altitudes, which additionally aggravate the lives of its inhabitants. For this reason, the migration trend and depopulation is quite understandable. The lowest population number is on the plateaus with slopes below $2^{\circ}$ which can be explained by the fact that because of the hill and mountain terrain character of the land relief itself, these terrains are generally represented to the smallest degree in the researched area.

The influence of the relief exposition on the distribution of population is mostly reflected in favourable circumstances for living. In this view, more favourable are southern and western expositions than northern and eastern ones. However, as for the relation between exposition and population distribution in the territory of East Sarajevo, the dominant trait is population on the west-oriented relief slopes (approximately 28\%) and then on the north-oriented slopes. This is explained by the configuration of the terrain itself, which because of its domineeringly mountain character with higher mountain areas in east and south, builds greater number of milder slopes on south-western, western and northern slopes which are also of lower altitudes. All of these parameters influenced greater population concentration on the relief to the west, southwest and north exposed sides, while the smallest percent of the population live on the northwest, northeast and south east slopes. Based on the data in Table 3. and Chart 3., the trends of population increase are evident, mostly to the west and southwestoriented slopes.

\section{Conclusion}

The analysis of the relief influence on the population distribution in the territory of the City of East Sarajevo showed itself as very interesting topic for research. While doing the paper, certain conclusions were made and also confirmations of previously set hypothesis on the influence that relief has on the distribution of population. 
It was affirmed that population of certain areas and its distribution greatly correspond to the outlined hypsometric levels, that is, that population distribution depends on altitude and that the areas of the City of East Sarajevo above the altitude of $1000 \mathrm{~m}$ are slightly populated. It has been noted that the most populated areas are those ranging between 800 and 1000 $\mathrm{m}$ altitudes, and then the areas ranging from $500-800 \mathrm{~m}$. This is the reason why $92,9 \%$ of the population is located in the zone to $1000 \mathrm{~m}$ altitude, while there is only $7,1 \%$ population in the areas over $1000 \mathrm{~m}$. The assumption that rural areas located on higher altitudes were more populated in earlier years (in comparison to 2013) has also been confirmed. Depopulation in rural areas is confirmed by the fact that number of settlements with less than 10 people increased since 1991 for $19 \%$, and since 1971 , even $23,6 \%$.

The research has showed that the greatest population is to the west-oriented slopes, while in relation to the sloping terrain, the biggest percentage of population (65\%) is located in the slopes ranging from $2^{\circ}$ to $5^{\circ}$, and then the slopes ranging from $5^{\circ}$ to $12^{\circ}(19 \%)$.

The hill and mountain relief, that dominates the researched area, distinguishes itself as the limiting population factor. These limitations are mostly reflected in the poor infrastructure connection, economy underdevelopment, and consequently prominent depopulation and population outflow. In the territory of East Sarajevo, the relief characteristics make it possible for the population to practice agriculture only partly, while the conditions for cattle farming are more favourable. The greatest number of population is located in the river valleys and basins situated between mountain massifs, where better life conditions are present as well as development of different economic activities. One of the advantages of mostly mountain relief in the territory of East Sarajevo is the possibility of mountain tourism development, especially winter mountain tourism, which is confirmed by the example of Jahorina and Trebevic mountains.

\section{References}

Državni zavod za statistiku Republike Hrvatske [Croatian Bureau of statistics Republic of Croatia].

(travanj 1995). Stanovništvo Bosne i Hercegovine - narodnosni sastav po naseljima [The population of Bosnia and Herzegovina - ethnic groups by settlements]. Zagreb: Autor.

Golijanin, J. (2012). Analiza fluvijalnog reljefa na širem prostoru Jahorine [Analysis of fluvial relief on the wider area of Jahorina]. U zborniku Nauka i identitet (str. 771-785). Pale: Univerzitet u

Istočnom Sarajevu, Filozofski fakultet.

Golijanin, J. i Lukić, M. (2012). Preobražaj vikend naselja i stanje vikendaških kretanja na geoprostoru

Paljanske kotline [The transformation of village cottages and the state of movement by weekend

on the geographical areas Pale's valley]. U zborniku Problemi i izazovi savremene geografske

nauke i nastave (613-620). Beograd: Univerzitet u Beogradu, Geografski fakultet.

Institute of Statistics Republic of Srpska. (2013). Census of population, households and dwellings in BH

2013. Banjaluka: Author.

Ivković, M. \& Todorić, J. (2013). Hypsometric distribution of the population in the settlements of Pirot

district. In Collection of Papers - Faculty of Geography at the University of Belgrade 61 (151-178). Belgrade: University of Belgrade, Faculty of Geography.

Lukić, M. (2011). Demografsko stanje grada Istočno Sarajevo [Demographic situacion of East Sarajevo].

U zborniku Treći kongres srpskih geografa (513-521). Banjaluka: Geografsko društvo Republike Srpske i Univerzitet u Banjaluci, Prirodnomatematički fakultet.

Lukić Tanović, M., Pašalić, S. \& Golijanin, J. (2014). Demographic development of Bosnia and

Herzegovina from the Ottoman period till 1991 and the modern demographic problems. Procedia Social and Behavioral Sciences, 120, 238-247.

Musa, S. (2005). Razmještaj naselja u Bosni i Hercegovini [Arrangement of settlements in Bosnia and

Herzegovina]. Mostariensia 22, 81-99.

Urbanistički zavod Republike Srpske [Institute of Planning Republca of Srpska]. (novembar, 2008). 
Prostorni plan grada Istočno Sarajevo do 2015 [Spatial Plan of the city of East Sarajevo till 2015]. Banjaluka: Autor. www.camo.ch

www.esri.com - National Geographic Basemap

www.viewfinderpanorams.org

Tables

Table 1. Population distribution according to hypsometric relief characteristics

\begin{tabular}{|c|c|c|c|c|c|c|}
\hline Elevation & $\begin{array}{l}\text { Number of } \\
\text { settlements }\end{array}$ & $\begin{array}{l}\text { Population } \\
1971\end{array}$ & 1981 & 1991 & 2013 & 2013.god. \\
\hline $500-600$ & 7 & 1844 & 2120 & 2557 & 23716 & \multirow{3}{*}{42} \\
\hline $600-700$ & 5 & 2899 & 3054 & 3169 & 2717 & \\
\hline $700-800$ & 12 & 1979 & 1541 & 1578 & 905 & \\
\hline $800-900$ & 49 & 15827 & 17461 & 21735 & 26630 & \multirow{2}{*}{50,9} \\
\hline $900-1000$ & 72 & 11456 & 10114 & 8016 & 6525 & \\
\hline $1000-1100$ & 34 & 5908 & 4792 & 4171 & 3094 & \multirow{5}{*}{7} \\
\hline $1100-1200$ & 17 & 3067 & 2243 & 2348 & 774 & \\
\hline $1200-1300$ & 12 & 1010 & 705 & 476 & 402 & \\
\hline $1300-1400$ & 6 & 649 & 481 & 367 & 284 & \\
\hline $1400-1500$ & 0 & 0 & 0 & 0 & 0 & \\
\hline $1500-1600$ & 2 & 60 & 21 & 13 & 47 & \multirow{2}{*}{0,1} \\
\hline$>1600$ & 0 & 0 & 0 & 0 & 0 & \\
\hline
\end{tabular}

Table 2. Population distribution according to the relief descent

\begin{tabular}{|c|c|c|c|c|c|c|}
\hline $\begin{array}{l}\text { Inclination } \\
\left({ }^{\circ}\right)\end{array}$ & $\begin{array}{l}\text { Number of } \\
\text { settlements }\end{array}$ & $\begin{array}{l}\text { Population } \\
1971\end{array}$ & 1981 & 1991 & 2013 & 2013. in $\%$ \\
\hline$<2$ & 1 & 0 & 0 & 0 & 3536 & 5,4 \\
\hline $2-5$ & 19 & 9837 & 12118 & 16647 & 42278 & 65 \\
\hline $5-12$ & 120 & 21902 & 19555 & 18028 & 12349 & 19 \\
\hline $12-32$ & 76 & 12960 & 10859 & 9755 & 6931 & 10,6 \\
\hline$>32$ & 0 & 0 & 0 & 0 & 0 & 0 \\
\hline
\end{tabular}

Table 3. Population distribution according to relief exposition characteristics

\begin{tabular}{lllllll}
\hline Slope aspect $\left(^{\circ}\right)$ & $\begin{array}{l}\text { Number } \\
\text { settlements }\end{array}$ & $\begin{array}{l}\text { of } \\
1971\end{array}$ & 1981 & 1991 & 2013 & 2013. in \% \\
\hline Horiz. površine & 0 & 0 & 0 & 0 & 0 & 0 \\
N & 31 & 9412 & 9917 & 11572 & 17339 & 26,6 \\
NE & 32 & 4901 & 3898 & 3369 & 1894 & 2,9 \\
E & 21 & 6503 & 7892 & 10003 & 9612 & 14,7
\end{tabular}




\begin{tabular}{lllllll} 
SE & 16 & 2336 & 1756 & 1573 & 1210 & 1,9 \\
S & 30 & 5296 & 4714 & 3577 & 2533 & 3,9 \\
SW & 47 & 7802 & 6088 & 5989 & 13985 & 21,5 \\
$W$ & 28 & 7151 & 7246 & 7460 & 18003 & 27,7 \\
NW & 11 & 1298 & 1021 & 887 & 518 & 0,8 \\
\hline
\end{tabular}

Figures

Figures 1. a) Geographical position of East Sarajevo within BH; (b) The location of municipalities and settlements in the East Sarajevo territory (Sourse: a www.camo.ch); b) www.esri.com)

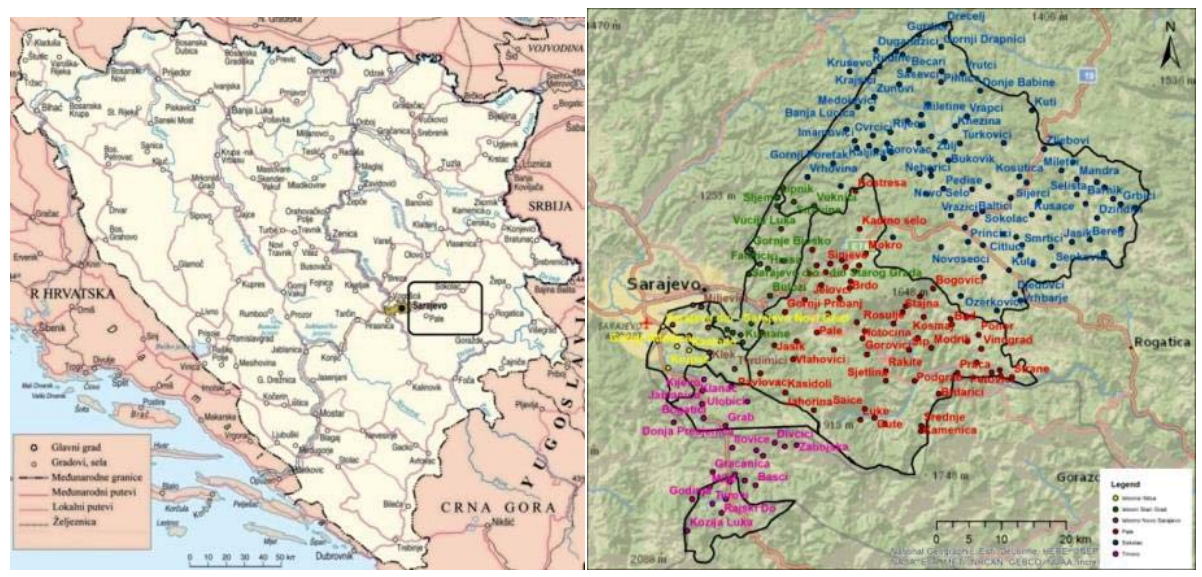

Figure 2. Morphometric land relief charts of the researched area with the settlements: (a) hypsometric chart of the City of East Sarajevo; (b) chart of relief descent of the City of East Sarajevo; (c) chart of relief exposition of the City of East Sarajevo
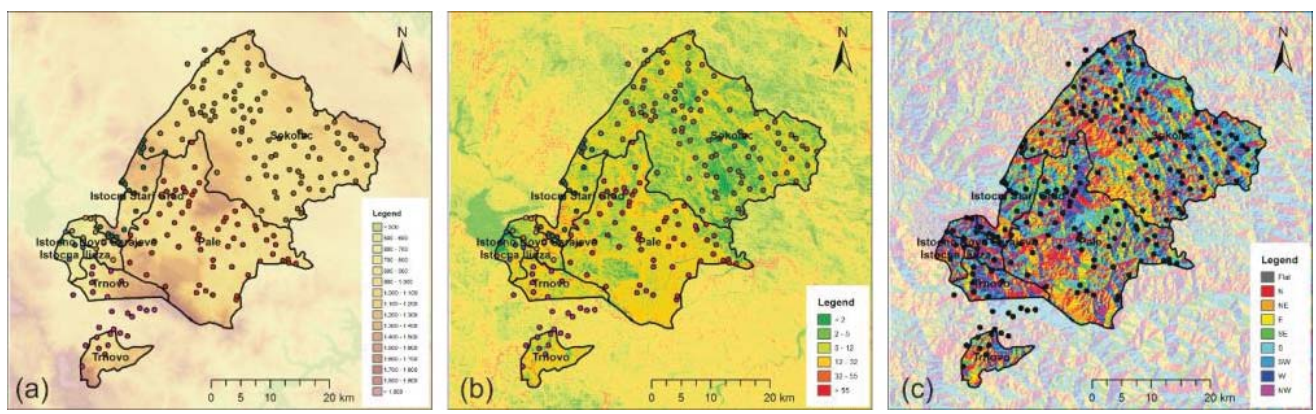

Chart 1. Relation between hypsometric relief characteristics and population in the territory of East Sarajevo 


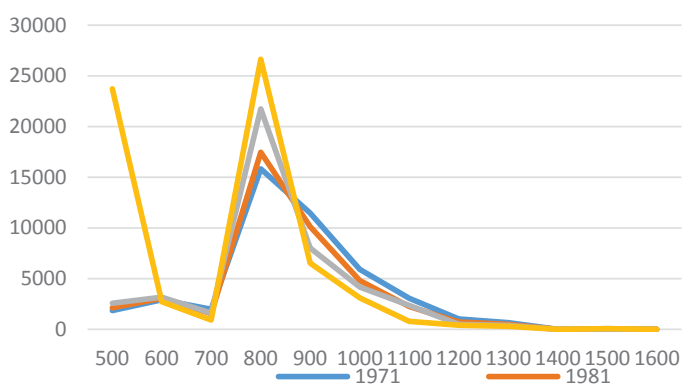

Chart 2. The relation between relief descent characteristics and population in the territory of East Sarajevo

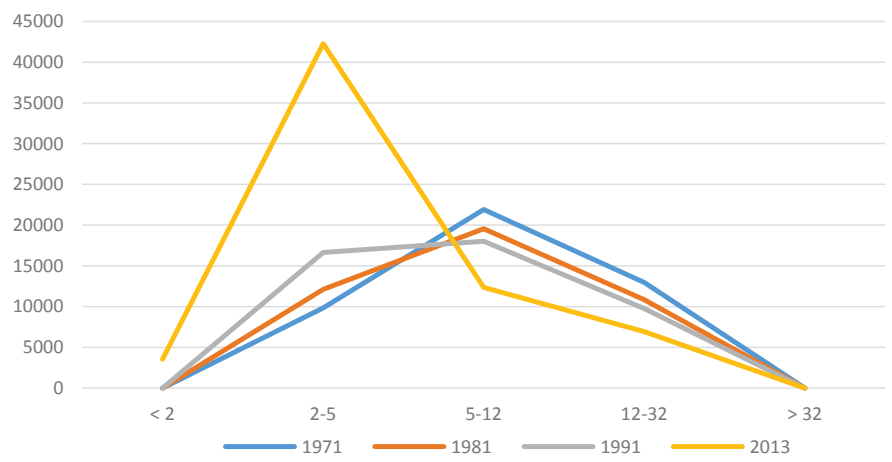

Chart 3. The relation between relief exposition characteristics and population in the territory of East Sarajevo

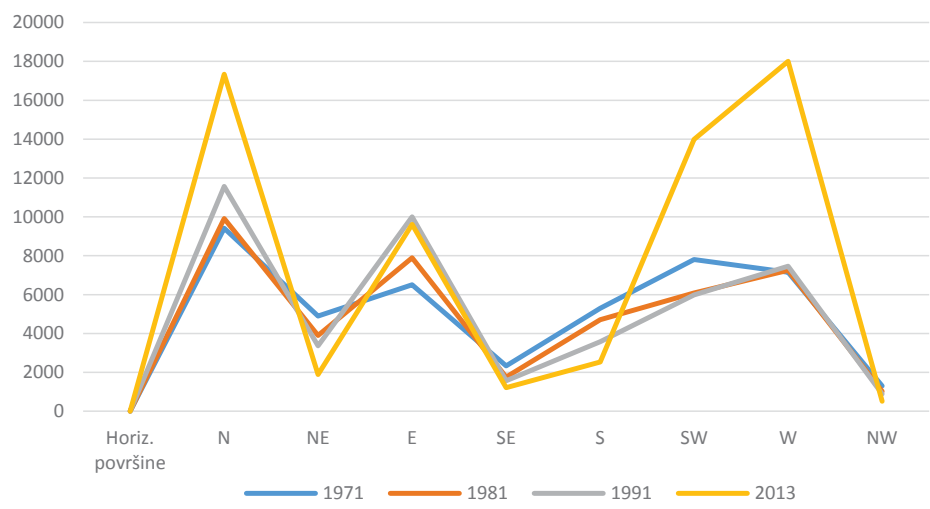

